$$
\text { CONF- } 960401--71
$$

UCRL-JC-124063

PREPRINT

\title{
Simulation of Mechanical Deformation and Tribology of Nano-Thin Amorphous Hydrogenated Carbon (a:CH) Films Using Molecular Dynamics
}

\author{
J.N. Glosli \\ M.R. Philpott \\ J. Belak
}

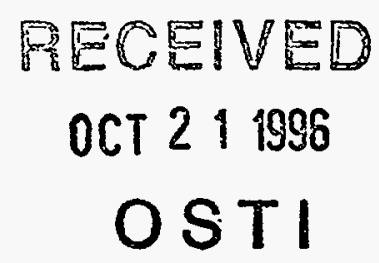

This paper was prepared for submittal to the Materials Research Society '96 Conference

San Francisco, $C A$

April 8-12, 1996

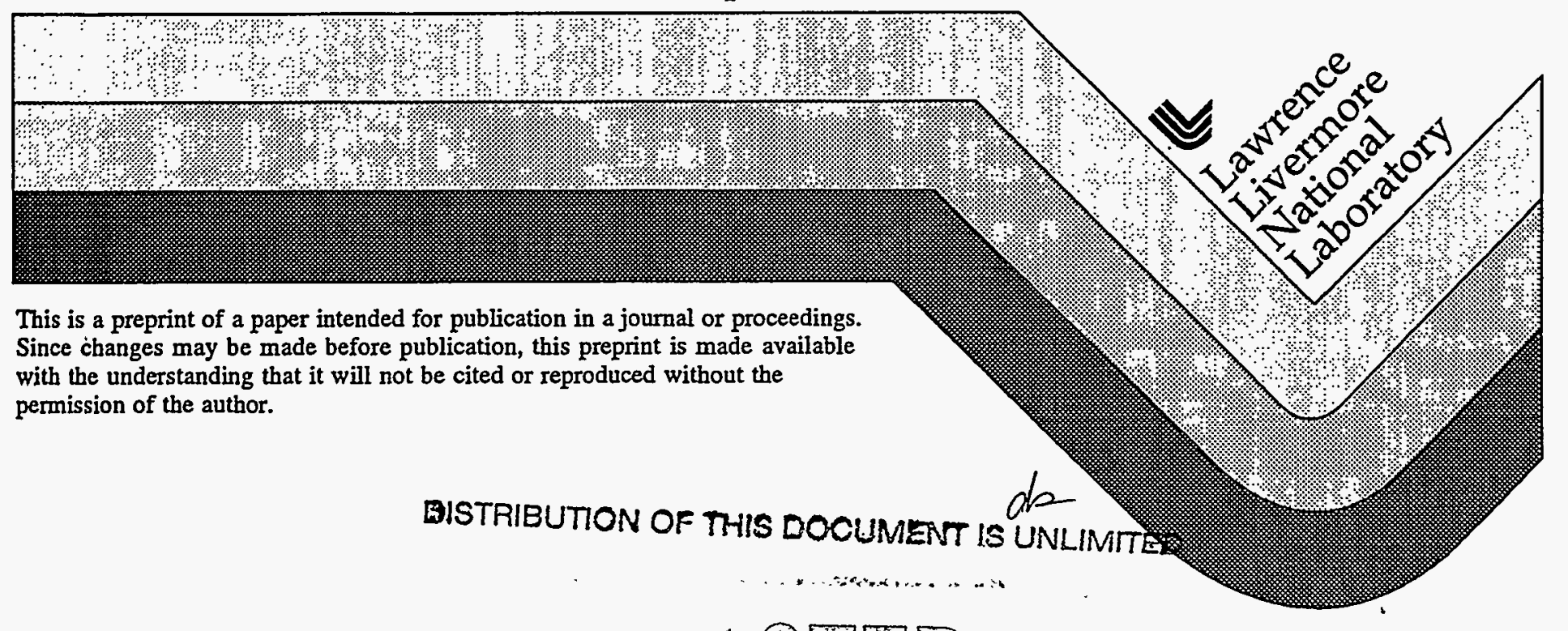

Since changes may be made before publication, this preprint is made available with the understanding that it will not be cited or reproduced without the permission of the author. 
DISCLAMMER

This document was prepared as an account of work sponsored by an agency of the United States Government. Neither the United States Government nor the University of California nor any of their employees, makes any warranty, express or implied, or assumes any legal liability or responsibility for the accuracy, completeness, or usefulness of any information, apparatus, product, or process disclosed, or represents that its use would not infringe privately owned rights. Reference herein to any specific commercial product, process, or service by trade name, trademark, manufacturer, or otherwise, does not necessarily constitute or imply its endorsement, recommendation, or favoring by the United States Government or the University of California. The views and opinions of authors expressed herein do not necessarily state or reflect those of the United States Government or the University of California, and shall not be used for advertising or product endorsement purposes. 


\section{DISCLAIMER}

Portions of this document may be illegible in electronic image products. Images are produced from the best available original document. 


\title{
SIMULATION OF MECHANICAL DEFORMATION AND TRIBOLOGY \\ OF NANO-THIN AMORPHOUS HYDROGENATED CARBON (a:CH) \\ FILMS USING MOLECULAR DYNAMICS
}

\section{J.N. GLOSLI*, M.R. PHILPOTT**, and J. BELAK*}

*University of California, Lawrence Livermore National Laboratory, Livermore CA 94550

**IBM Research Division, Almaden Research Center, 650 Harry Road, San Jose, CA 95120-6099

\begin{abstract}
Molecular dynamics computer simulations are used to study the effect of substrate temperature on the microstructure of deposited amorphous hydrogenated carbon $(\mathrm{a}: \mathrm{CH})$ films. A transition from dense diamond-like films to porous graphite-like films is observed between substrate temperatures of $400 \mathrm{~K}$ and $600 \mathrm{~K}$ for a deposition energy of $20 \mathrm{eV}$. The dense a:CH film grown at $300 \mathrm{~K}$ and $20 \mathrm{eV}$ has a hardness ( $-50 \mathrm{GPa})$ about half that of a pure carbon (a:C) film grown under the same conditions.
\end{abstract}

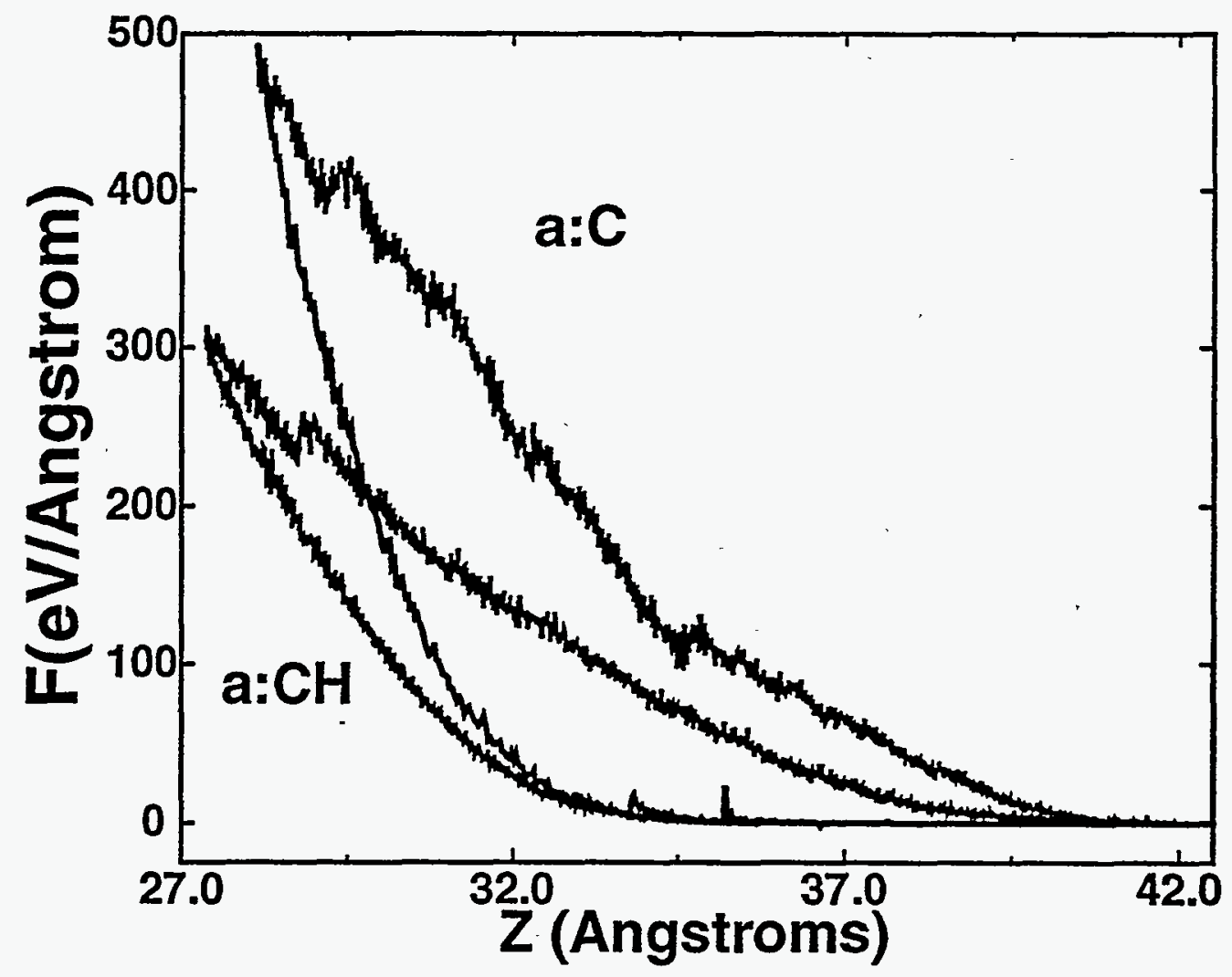

Figure 1. The indentation loading and unloading curves for simulated amorphous carbon films. The upper curve is for a:C and the lower curve is for a:CH. Both films were grown with $20 \mathrm{eV}$ deposition energy, $300 \mathrm{~K}$ substrate temperature and $4 \mathrm{~nm}$ surface cells. The estimated hardness of the a:C films is $\sim 100 \mathrm{GPa}$ and that of the a:CH film is $\sim 50 \mathrm{GPa}$. 


\section{INTRODUCTION}

Amorphous carbon films about 20nm thick are used throughout the magnetic disk industry as protective coatings on magnetic disks. Despite intense experimental and theoretical study $[1,2]$, the microstructure of these amorphous films and the effect on mechanical properties such as hardness is not well understood. This is in part due to the variety of deposition methods used and to the difficulty in probing the state of the material at the nanometer length scale.

In this work we use a molecular dynamics computer model [3,4] with a reactive bondorder interatomic potential $[5,6]$ to simulate the growth and resulting hardness of hydrogenated amorphous carbon films. This potential model represents the chemistry of the carbon/hydrogen system allowing the formation of both graphitic and diamond-like regions. The films are created by depositing a 50/50 mixture carbon and hydrogen atoms onto a diamond (100) surface (12 layers) at one atom per picosecond. The substrate temperature is controlled with a Nose-Hoover thermostat and with a Langevin thermostat. A time step of $0.5 \mathrm{fs}$ is used and the simulation cell is periodic in the plane of the surface. Cell sizes of $2 \mathrm{~nm}$ and $4 \mathrm{~nm}$ are considered. Indentation was performed at $35 \mathrm{~m} / \mathrm{s}$ using a tip cleaved from three $(100)$ planes on the diamond lattice. The tip was blunted to create an effective radius of about $1 \mathrm{~nm}$. The tip atoms are held rigid during the indentation and interact with the surface atoms through a truncated Lennard-Jones potential. The indentation rate of $35 \mathrm{~m} / \mathrm{s}$ is comparable to the sliding speeds at the head-disk interface in magnetic recording disks.

\section{RESULTS and DISCUSSION}

Shown in Figure 1 is the loading and unloading curves (force on the indenter as a function of height) for simulations of both $\mathrm{a}: \mathrm{C}$ and $\mathrm{a}: \mathrm{CH}$ films. The results for the $\mathrm{a}: \mathrm{C}$ films are presented in reference 4 . Both films were grown with a $4 \mathrm{~nm}$ surface cell, a substrate temperature of $300 \mathrm{~K}$, and a deposition energy of $20 \mathrm{eV}$. The indentation computer experiment was performed at $35 \mathrm{~m} / \mathrm{s}$ as described above. The step-like kinks in the loading curves are due to the onset of plasticity. Unloading the tip prior to the first step does not give the hysteresis loop as shown. Our simulation cell is too small to observe the formation of cracks and plasticity occurs through changes in the chemical bonding network. The simulated pure carbon film is about twice as hard as the simulated hydrogenated carbon film. We estimate the hardness from the loading curves and the area of contact $(\mathrm{H}=\mathrm{L} / \mathrm{A})$ to be $\sim 100 \mathrm{GPa}$ for the pure carbon film and $\sim 50 \mathrm{GPa}$ for the hydrogenated carbon film.

Substrate temperature is an important control variable determining the microstructure and hence properties of amorphous carbon films. To investigate the effect of substrate temperature we performed a series of deposition simulations ranging in temperature from $150 \mathrm{~K}$ to $600 \mathrm{~K}$ at $20 \mathrm{eV}$ using a $2 \mathrm{~nm}$ surface cell. Snapshots from these simulations are shown in Figure 2 . The microstructure of the low temperature $(150 \mathrm{~K})$ film is qualitatively the same as the film grown at room temperature $(300 \mathrm{~K})$. The bonding at $20 \mathrm{eV}$ is dominated by $\mathrm{sp}^{3}$ hybridized carbon (diamond-like) with a small amount of $\mathrm{sp}^{2}$ (graphitic) $[3,4]$. The presence of hydrogen tends to stabilize the diamond-like carbon and the graphitic carbon atoms tend to come in pairs. The microstructure at $400 \mathrm{~K}$ is also qualitatively the same as at $300 \mathrm{~K}$. Between $400 \mathrm{~K}$ and $600 \mathrm{~K}$ we find a transition to a porous structure dominated by graphitic bonding. The snapshot at $600 \mathrm{~K}$ displays large voided regions within the film. In a recent experimental study of the effect of substrate temperature on the 

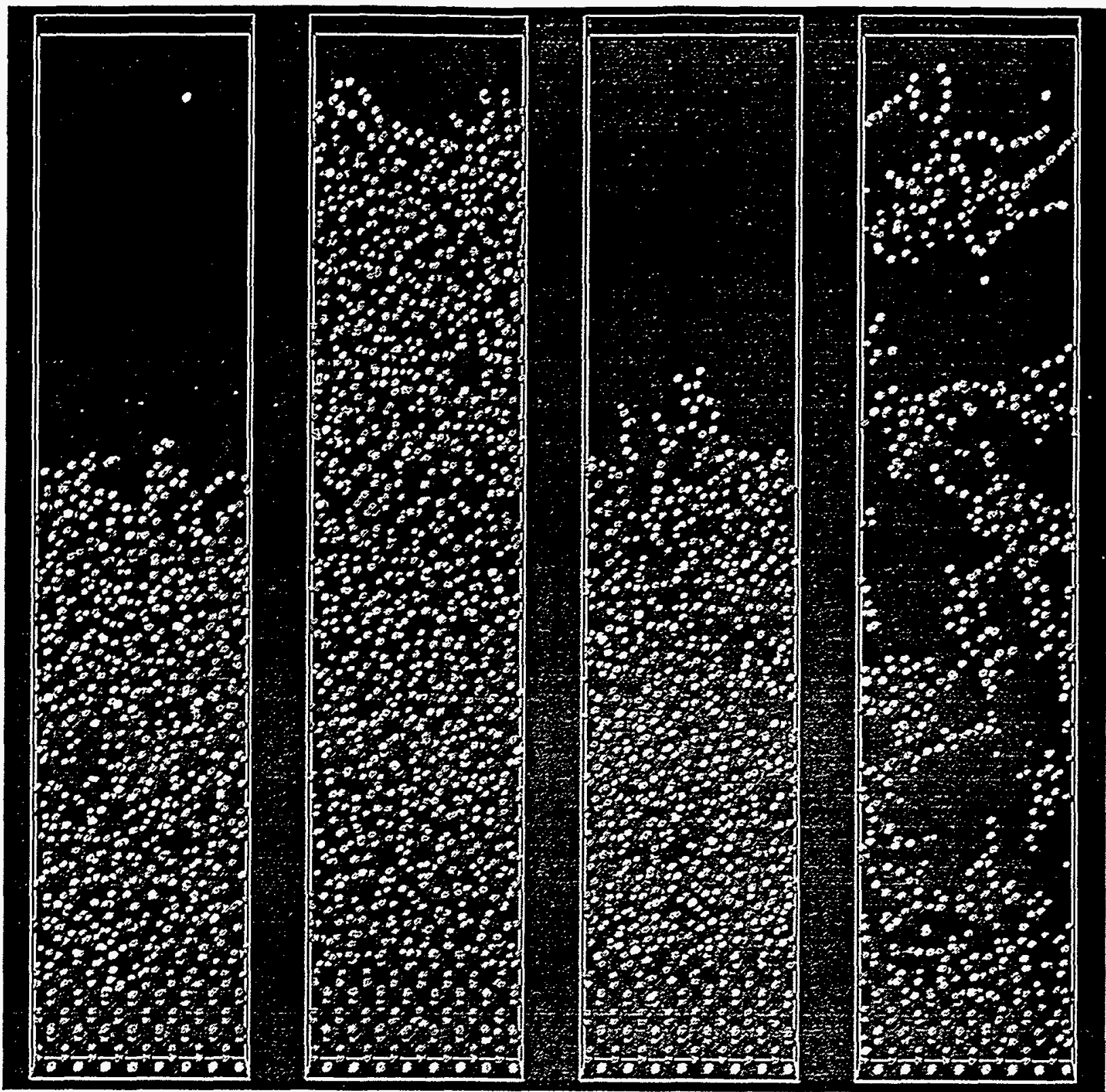

$$
\mathrm{T}=150 \mathrm{~K}
$$

$$
\mathrm{T}=300 \mathrm{~K}
$$

$\mathrm{T}=400 \mathrm{~K}$

$T=600 \mathrm{~K}$

Figure 2. Snapshots from our computer simulations of the growth of hydrogenated amorphous carbon films. The four snapshots are for substrate temperatures of $150 \mathrm{~K}, 300 \mathrm{~K}, 400 \mathrm{~K}$, and $600 \mathrm{~K}$. All simulations were for $20 \mathrm{eV}$ deposition energy, a $2 \mathrm{~nm}$ surface cell, $0.5 \mathrm{fs}$ time step and a 50/50 mixture of carbon and hydrogen atoms being deposited.

microstructure of nonhydrogenated carbon films, Bhargava et. al [7] found an observable difference between films grown at a substrate temperature of $400 \mathrm{~K}$ and films grown at $800 \mathrm{~K}$. Their micro-Raman spectra suggest a significantly greater graphitic character for the high temperature films. The computer simulations presented here are consistent with that interpretation. 


\section{ACKNOWLEDGEMENTS}

Work performed under the auspices of the U.S. Department of Energy by Lawrence Livermore National Laboratory under contract No. W-7405-ENG-48.

\section{REFERENCES}

(1) H-C. Tsai and D.B. Bogy, J. Vac. Sci. Tech., A5, 3287 (1987).

(2) A. Grill, Wear, 168, 143 (1993).

(3) J.N. Glosli, J. Belak, and M.R. Philpott, "Ultra-Thin Carbon Coatings for Head-Disk Interface Tribology," in Thin Films: Stresses and Mechanical Properties V, S.P. Baker, C.A. Ross, P.H. Townsend, C.A. Volkert, and P. Borgesen eds., MRS Symposium Proceedings 356, MRS, Pittsburgh, USA 1995.

(4) J.N. Glosli, M.R. Philpott, and J. Belak, "Molecular Dynamics Simulation of Mechanical Deformation of Ultra-Thin Amorphous Carbon Films," in Mechanical Behavior of Diamond and Other Forms of Carbon, M.D. Drory, M.S. Donley, D. Bogy, and J.E. Field eds., MRS Symposium Proceedings, MRS, Pittsburgh, USA, 1995.

(5) D.W. Brenner, Phys. Rev. B42, 9458 (1990).

(6) D.W. Brenner, J.A. Harrison, C.T. White, and R.J. Colton, Thin Solid Films 206, 220 (1991).

(7) S. Bhargava, H.D. Bist, A.V. Narliker, S.B. Samanta, J. Narayan, and H.B. Tripathi, J. Appl. Phys 79, 1917 (1996). 